\section{Leseverdig om antisosialitet}

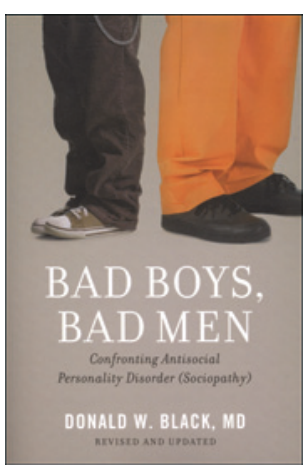

Donald W. Black

Bad boys, bad men

Confronting antisocial personality disorder

(sociopathy). 2. utg. 318 s, ill. Oxford: Oxford

University Press, 2013. Pris GBP 15

ISBN 978-0-19-986203-0

Målgruppen er alle - både fagpersoner og menigmann - som ønsker å lære mer om antisosial atferd, psykopati, sosiopati og antisosial personlighetsforstyrrelse. Første utgave kom i 1999, og denne reviderte utgaven er oppdatert når det gjelder ny viten om antisosial personlighetsforstyrrelse. Spesielt er den oppdatert med tanke på kvinner som har en antisosial personlighetsforstyrrelse. Forfatteren er professor i psykiatri og har lang fartstid som forsker og skribent.

I de 10 kapitlene tar forfatteren i tur og orden for seg hvordan samfunnet og medisinen (psykiatrien) har sett på antisosiale trekk gjennom historien, symptomer og diagnostiske kriterier, årsaker både miljø og biologi, ulike former for behandling, beskrivelse av personer med mer «velfungerende» antisosiale personlighetstrekk kontra den dårlig fungerende og alvorlig forstyrrede seriemorderen. Avslutningsvis er det en fyldig og beskrivende litteraturliste og forslag til videre lesning.

Boken er lettlest, og språket er flytende uten fagsjargong og fremmedord. En rekke illustrative og spennende pasienthistorier gir boken preg av å være en roman snarere enn en fagbok. Vi får komprimerte livshistorier som er illustrative for denne lidelsen, og som beskriver hvordan symptomene på antisosialitet kan forstås. Dette gjelder ikke minst mangelen på å føye seg etter sosiale normer, løgner, aggresjon, uro, uansvarlighet, mangel på anger og empati og kriminalitet. Personenes minimale evne til introspeksjon, til selv å ta ansvar for sine handlinger og å skylde på alle andre for hvordan de selv har det, blir godt beskrevet.

Boken gir et mer optimistisk bilde av behandlingen av personer med en antisosial personlighetsforstyrrelse enn tidligere bøker. Forfatteren hevder at det er blitt en myte blant fagfolk at ingen former for behandling hjelper for denne pasientgruppen. Selv om det ikke finnes mange gode randomiserte studier, hevder forfatteren at den pessimismen som har bredt seg, til dels er feil og må bekjempes. Kognitiv atferdsterapi blir beskrevet mest inngående.

Det finnes mange bra bøker om psykopati og antisosial personlighetsforstyrrelse på norsk. Boken til Dalsegg og Wesche (1) er et godt eksempel og utfyller Blacks bok på en glimrende måte. Dette gjelder både det faglige og det å prøve å forstå hva antisosial personlighetsforstyrrelse er, og hvordan personer med antisosial personlighetsforstyrrelse kan ramme personer de møter. Jeg kan trygt anbefale boken til leger i alle spesialiteter. Den beskriver et emne de fleste av oss vil ha befatning med i vår kliniske praksis.

\section{Jan Ivar Røssberg}

Institutt for klinisk medisin

Universitetet i Oslo

\section{Litteratur}

1. Røssberg JI. Helsefarlige relasjoner. Anmeldelse av: Dalsegg A, Wesche I. Ut av psykopatens grep. Hvordan komme fri fra helsefarlige mennesker. Tidsskr Nor Legeforen 2008; 17: 1993.

\section{God innføring, men ikke helt «at a glance»}

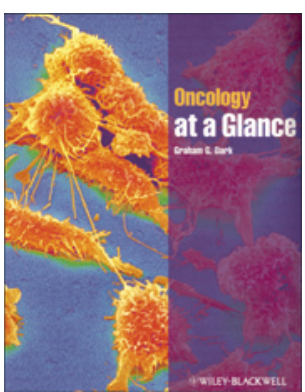

\author{
Graham G. Dark
} Oncology at a glance

123 s, tab, ill. Chichester: Wiley Blackwell, 2013. Pris GBP 25

ISBN 978-11-183-6969-2

At a glance-serien henvender seg først og fremst til medisinstudenter. Hvert kapittel kombinerer en side med tegninger og diagrammer vendt mot en side med tekst, slik at et raskt overblikk ved senere repetisjon burde kunne gi en oppfriskning av stoffet. Oncology at a glance er en svært god introduksjonsbok til generelle onkologiske temaer, en helt grei bok til spesifikke onkologiske sykdommer, men møter ikke helt forventningen om å gi rask repetisjon ved et kort overblikk.

Språket er kort og konsist, og grunnleggende begreper forklares ofte underveis. En stor del av medisinstudiet handler om å sette seg inn i en ny verden av nomenklatur og forkortelser. I den generelle delen forklares tumornavngiving fint, og det er vedlagt liste over forkortelser og en ordliste, men disse kunne med fordel vært noe mer utfyllende. Videre er det flere konsepter som forblir uforklarte, og hvor fotnoter kunne blitt brukt, slik at man slapp å slå opp $i$ andre kilder - for det er vel derfor man kjøpte en egen bok om kreft i utgangspunktet?

Det er oversikter over kreft blant annet etter miljøfaktorer, assosiasjon til arvelige syndromer, lokal symptomatologi og hormonelle risikofaktorer. Kapitlet om kommunikasjon er hjelpsomt, med gode tips til hvordan å gi dårlige nyheter. Andre plansjer omtaler øyeblikkelig hjelp-situasjoner, metastaseutredning, kreft med ukjent utgangspunkt, patologiske mekanismer bak kreftsykdom og prinsippene bak kjemoterapi og stråling. Det skrives om multidisiplinære møter, kvalmehåndtering og smertebehandling. Hvis de nye studentene leser første del grundig, vil de være godt forberedt til å møte kreftsykdom i undervisningen.

I de organspesifikke kapitlene er det derimot et par punkter som kan forbedres. Der bøkene om medisin og kirurgi i samme serie er godt illustrert og veldig informative, mangler denne boken skikkelige tegninger og bilder. I stedet er det brukt rotete diagrammer. Jeg savner bilder av organene og tegninger som eksemplifiserer stadieinndeling.

Variasjonen i screeningprogrammer mellom Norge og Storbritannia kan lett suppleres ved et kjapt søk på nettet. En oversikt over forekomst og dødelighet etter type kreft mangler. Forfatteren er lite konsekvent med bruk av uthevet skrift for å lage integrerte oppsummeringer av f.eks. behandlingsalternativer. Dette er leit og tvinger frem markeringstusjen. Karcinomatose er ikke gjort rede for, ei heller trofoblastsvulster og kreft i vulva og penis. Ellers er det meste dekket. Utredning av kul i brystet og kul i halsen kunne også vært mer elegant fremstilt - ord som trippel- og kvadruppeldiagnostikk blir ikke nevnt.

Den første generelle delen er meget god. Mangelen på illustrasjon i den organspesifikke delen er en stor svakhet. Jeg vil allikevel anbefale den som en rask introduksjon til et omfattende emne.

\section{Stian Wendelborg}

Universitetet i Oslo 